Emir. J. Food Agric. 2011. 23 (1): 80-94

http://ejfa.info

\title{
Utilization of treated sewage wastewater for green forage production in a hydroponic system
}

\author{
Ghazi N. Al-Karaki* \\ Faculty of Agriculture, Jordan University of Science \& Technology, Irbid, Jordan
}

\begin{abstract}
Using alternative water resources such as tertiary treated sewage wastewater is considered very important to produce crops (e.g., green forage) due to irrigation water shortage, especially in arid and semiarid regions like Jordan. Moreover, growing forage hydroponically is now becoming popular in drought prone areas to produce green fodders in large quantities with less water use. The objectives of this study were to investigate the effects of irrigation with tertiary sewage treated wastewater (WW), tap water (TW) or mixed WW with tap water (WW mix) on barley (Hordeum vulgare L.) fodder yield, quality, and water use efficiency (WUE) under hydroponic conditions. A hydroponic system was developed with four shelves and used in this study. The results showed that barley forage can be produced in 9 days from planting to harvest in this system. Using WW in irrigation has effectively increased the yields of green and dry fodder, and the green forage yields obtained were 224, 276 and 320 tons/ha under irrigation with TW, WW mix and WW, respectively. The higher fodder yields obtained with WW than TW or WW mix, probably due to the higher nutritive value of WW especially $\mathrm{N}$ content. However, plants irrigated with WW used water more efficiently than those irrigated with other water types, when used $1.26 \mathrm{~m} 3$ compared to $1.56 \mathrm{~m} 3$ water in TW to produce 1 ton of hydroponic green fodder. Proximate and mineral nutrient contents of dry fodder were significantly higher in plants irrigated with WW than with TW in respect to crude protein, acid and neutral detergent fiber, and $\mathrm{N}, \mathrm{K}, \mathrm{Mg}$, and $\mathrm{Na}$ contents. Heavy metal $(\mathrm{Cd}, \mathrm{Pb}$, and $\mathrm{Ni}$ ) contents in barley fodder were higher in plants irrigated with WW than those irrigated with TW, but their levels did not reached the maximum allowed levels by FAO for edible crops. The results of this study revealed that hydroponic green barley fodder could be irrigated safely with tertiary treated sewage wastewater to produce high yields and less water use. Moreover, use of treated wastewater in irrigation of green forages in hydroponic system considered as useful alternative disposal method of wastewater without the risk of accumulation of heavy metals in the soil.
\end{abstract}

Keywords: Treated sewage, green forage, water use efficiency, heavy metals, soilless.

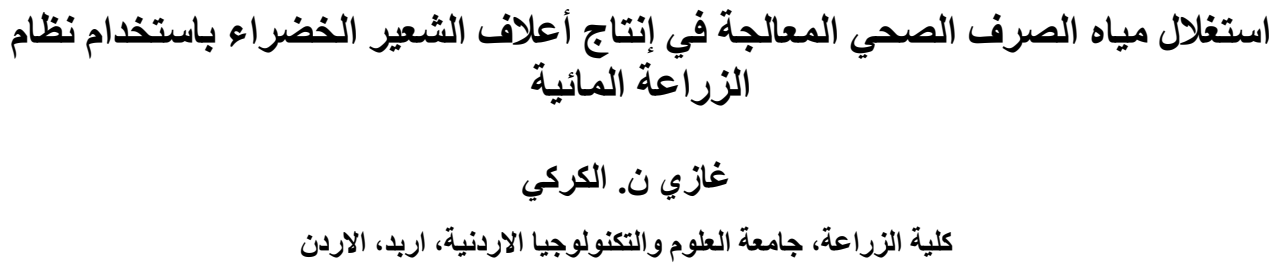

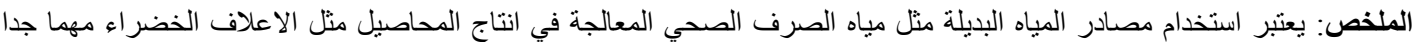

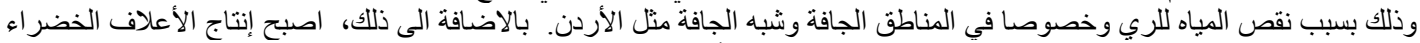

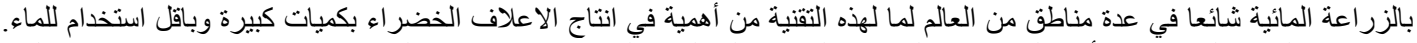

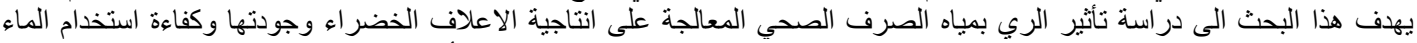

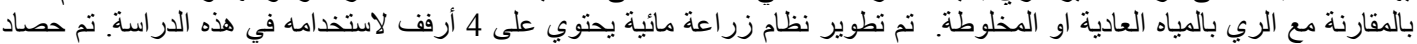

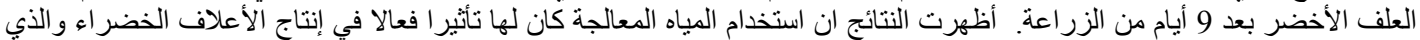

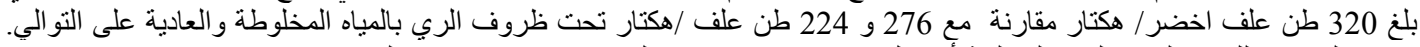

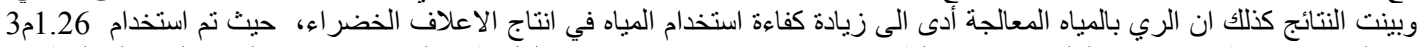

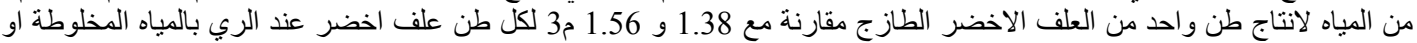

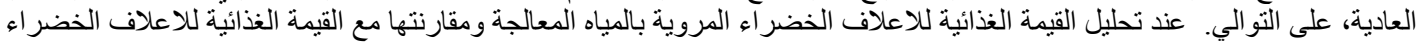

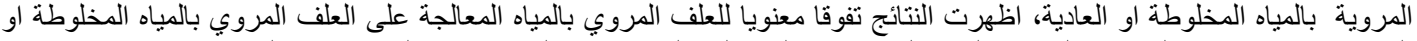

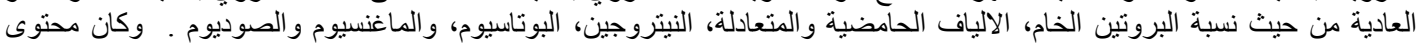

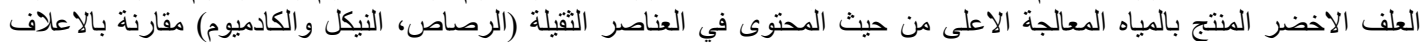

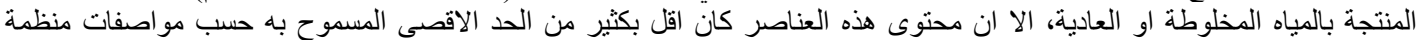

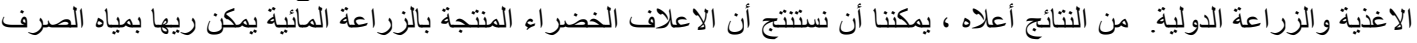

* Corresponding Author, Email: gkaraki@just.edu.jo 
Ghazi N. Al-Karaki

الصحي المعالجة ثلاثثا من اجل زيادة الانتاجية وباستخدام اقل من المياه وكطريقة بديلة للتخلص من المياه العادمة وبدون وجود اي تأثئيرات

سلبية متل تر اكم العناصر الثقيلة في التربة المروية بالمياه الدعالجة مع مرور الوقت.

\section{Introduction}

Growing water scarcity threatens economic development, sustainable human livelihoods, environmental quality, and a host of other societal goals in countries and regions around the world. The water scarcity in Jordan for example poses a serious challenge for all sectors of water consumption (agriculture, domestic, and industry); with the agricultural sector being the most affected one that consumes about $65 \%$ of the available water (Malkawi, 2007). Jordan as well as many other countries in the region is struggling to keep up with the demand for fresh water (Malkawi, 2007; Al-Karaki and Al-Momani, 2010). However, over-exploitation of water resources (mainly ground water) has lead to deterioration in the quantity and quality of irrigation water and the booming population is jeopardizing long-term water supplies. This would lead to the reduction of irrigated areas and the change towards cropping systems with lower water demands or utilizing lower quality sources of water (e.g., treated wastewater). The use of wastewater in agriculture is increasing due to water scarcity, population growth, and urbanization, which all lead to the generation of yet more wastewater in urban areas. By 2020, the volume of treated wastewater (WW) in Jordan for example is expected to reach about 230 million $\mathrm{m}^{3}$ (Al-Ghazawi et al., 2007). Wastewater reuse in agriculture represents a potentially important alternative for fresh water and save it for drinking and industry water supplies.

The use of WW in agriculture needs to be done with precautions to avoid harming the agricultural soils and to prevent any consumer health risk. Therefore, use of treated wastewater in agriculture in Jordan was largely limited to irrigation of forages and forestry (Nsheiwat, 2007).

The popular treatment process for sewage in Jordan and some other countries in the region is the use of stabilization pond to separate sewage sludge from WW. The secondary stage is an oxidation stage where most of the organic matter is converted into more stable forms by bacteria (Malkawi and Mohammad, 2003). A tertiary treatment stage is used to reduce the risks associated with the use of secondary treated effluent mainly bacteria and heavy metal concentrations. Although the uptake of heavy metals by plants might reduce the concentration of these elements that might accumulate in the soil and surface waters due to irrigation with WW, Hook (1981) reported that good management of the soil plant system is needed to minimize pollution of ground water. However, extended wastewater application in irrigation of crops might result in accumulation of heavy metals in soils and hence might cause soil deterioration and ground water pollution (Malkawi and Mohammad, 2003; Sidle et al., 1977; Xua etal., 2010).

Recent studies have indicated that nutrients from treated wastewater could be purified by using some plant species in a hydroponic system (Vaillant et al., 2004; Yang et al., 2008; Snow and Ghaly, 2008; Rababah and Ashbolt, 2000; Rababah and al-Shuha, 2009). Moreover, hydroponics (soilless) culture could lead to solve the global issues such as the shortage of water, environmental pollution, and instability of ecological system in various ways. Constituting high values for agricultural crops by using low water inputs and high fertilizer efficiencies is one of the methods used in addressing the environmental and resource problems (Sezen et al., 2010). Hydroponic culture could be arranged with optimum environmental medium for crop growth in order to gain maximum yield and high quality products.

Due to the rapidly growth population in Jordan as well as many other countries in the region, the demand for food and livestock products increases, and this becomes a challenge for the animal production sector to meet this rapidly increased demand with the 
prevailing production conditions (e.g., water shortage). The major constraints on livestock production in Jordan and the other countries in the arid and semiarid regions are the inadequate quantities and poor quality of the produced forages (e.g. green forage) in addition to the high cost of imported feed (Al-Karaki, 2010; Ansar et al., 2010; Al-Hashimi, 2008). Local production of forages in Jordan for example covers only about $20 \%$ of its livestock requirements (Harb and Awawdeh, 2008), and this is mainly due to the limitation in water resources that is needed for forage production. These conditions force the Jordanian government to import the rest of livestock sector forage requirements from abroad, which in turn led to the increased forage prices. In 2007 for example, forage prices in Jordan increased by about $150 \%$ with increasing of animal products prices as a consequence (MOA, 2008). Therefore, Jordan needs to increase its fodder production with good quality, in large amounts, and in appropriate cost to feed its grazing animals.

Achieving a suitable green fodder production under the prevailing water-scarcity conditions in Jordan and other countries in the region, requires the introduction and implementation of low quality water (treated wastewater) and agricultural techniques which minimize the water consumption and improve yield per unit of water used. One of the modern techniques that are considered important for better water use efficiency as well as for fodder production is hydroponic culture. Hydroponic fodder production is a well-known technique for high fodder yield, year round production and least water consumption (Tudor et al., 2003; Cuddeford, 1989; Al-Karaki, 2008). Al-Karaki (2010) has reported that about 1.5-2 liters are needed to produce $1 \mathrm{~kg}$ of green fodder hydroponically in comparison to $73.5,85.5$, and 167 liters to produce $1 \mathrm{~kg}$ of green fodder of forage barley, alfalfa, and Rhodes grass under field conditions in Sultanate of Oman. Fodder produced hydroponically has a short growth period 7-10 days and requires only a small piece of land for production to take place (Mooney, 2005;
Cuddeford, 1989). It has high feed quality, rich with proteins, fibers, vitamins, and minerals (Chung et al., 1989; Leontovich and Bobro, 2005; Al-Karaki and Al-Momani, 2010) with therapeutic effects on animals (Kanauchi et al., 1998; Boue et al., 2003). All these special features of hydroponic culture, in addition to others make it one of the most important agricultural techniques currently in use for green forage production in many countries especially in arid and semi-arid regions.

The current study aimed at to investigate green fodder yield, water use efficiency, and quality and heavy metal contents of the hydroponically produced barley fodder using tertiary treated sewage wastewater for irrigation and compare it with tap water irrigation.

\section{Materials and Methods}

The research has been carried out during 2010 at the growth room of the Plant Physiology Laboratory, Faculty of Agriculture, Jordan University of Science and Technology, Irbid, Jordan. A hydroponic system was developed and manufactured at a local workshop used in this study.

\section{The hydroponic system}

The hydroponic system is composed of two cabinets (units) with metal frame and four shelves each with a length of $200 \mathrm{~cm}$, a width of $55 \mathrm{~cm}$, and a height of $240 \mathrm{~cm}$. Each unit of the system could carry 28 planting trays with capacity to produce approximately $80-100 \mathrm{~kg}$ green fodder per growth cycle (9 days), depending on crop variety and growth conditions (Al-Karaki and Al-Momani, 2010). The horizontal area occupied by each unit of the system was about $2 \mathrm{~m}^{2}$ including the walkway between neighboring units. However, the number of units of the hydroponic system can be increased and planting date scheduled for daily production of green fodder to meet the daily demand of animals in the farm. Polystyrene trays with a length of $45 \mathrm{~cm}$, a width of $25 \mathrm{~cm}$ and a depth of $8 \mathrm{~cm}$ were used for growing seeds to produce green fodder. These trays were obtained from the local market. The units of hydroponic system have 
been arranged in the growth room close to window to utilize natural illumination. An air conditioning unit was used to control temperature inside the growth room which was maintained at $24 \pm 2^{\circ} \mathrm{C}$. The relative humidity in the growth room ranged between 50 and $73 \%$.

\section{Plant material}

Local barley cultivar was selected and used in this study according to the results obtained by Al-Karaki and Al-Momani (2010) that indicated this cultivar out yielded the other tested cultivars for green fodder production under hydroponic conditions. Seeds of this cultivar are composed from a mixture of landraces and were obtained from the local market of Irbid, Jordan. Seeds were subjected to a germination test to check for their viability before being used; the results showed that the germination percentage was $95 \%$.

\section{Treatment of seeds and planting}

Seeds of barley were cleaned from debris and other foreign materials. Then the cleaned seeds were surface sterilized by soaking for 30 minutes in a $20 \%$ sodium hypochlorite solution (Clorox bleach) to prevent the formation of mould. Planting trays and the growing cabinet also were cleaned and disinfected. The seeds were washed well from residues of bleach and re-soaked in tap water overnight (about 12 hours) before sowing.

Seeds were sown in the polystyrene trays lined with black plastic sheets and have holes at the bottom to allow drainage of excess water from irrigation. The seeding rate used in this experiment was about $450 \mathrm{~g} /$ tray (equivalent to about $\left.4.0 \mathrm{~kg} / \mathrm{m}^{2}\right)$. The trays were stacked on the shelves ( 7 trays per shelf in each hydroponic unit).

\section{Irrigation treatments}

Trays were irrigated daily with three water types: tertiary sewage treated wastewater (WW), tap water (TW), and mixture of equal amounts of WW and TW (WW mix). The treated wastewater was obtained from the Jordan University of Science and Technology (JUST) treatment plant located inside the campus (total area of JUST campus about 1100 ha). JUST plant is currently operating at about
$600 \mathrm{~m}^{3}$ / day with a capacity of $2,500 \mathrm{~m}^{3}$ / day (Al-Ghazawi et al., 2008).

\section{Water use efficiency}

Planting trays were irrigated twice a day from each water type (early in the morning and late in the afternoon) to provide enough water to keep the seeds / seedlings moist. Daily amounts of water used in irrigation were recorded to compute the total amounts used in irrigation throughout the experiment. Drained water out of irrigation was collected in plastic trays which were placed under each planting tray were also recorded. The total water used by plants (liters/tray) was computed as the following:

Total water use (liters/tray) $=$ Total added water in irrigation- Total drained water out of trays

Water use efficiency (WUE) was computed according to:

WUE $=$ tons green fodder produced $/ \mathrm{m}^{3}$ water used.

\section{Fodder yield}

At the end of experiment ( 9 days after seeding), the produced green fodder was ready for harvest, and green plants with their root mats in the trays (Figure 1) were harvested and the following data were recorded: total fresh and dry fodder yields, seedling height, and conversion factor (ratio of produced green fodder to the initial planted seed weight).

\section{Proximate chemical composition analysis}

A representative fresh plant samples (about 150 grams) from every tray were taken at harvest, oven-dried at $70^{\circ} \mathrm{C}$ for 48 hours, weighed, and stored for chemical analysis. To study the nutritional value of produced fodder, proximate analysis for collected samples was conducted and crude protein, crude fiber, crude lipid, and dry matter contents were determined according to the procedures of AOAC (2000). Acid detergent fiber (ADF) was determined using acetyl trimethyl ammonium bromide and $1 \mathrm{~N} \mathrm{H}_{2} \mathrm{SO}_{4}$ (Robertson and Van Soest, 1981). Neutral detergent fiber (NDF) was determined using sodium sulphite and sodium lauryl sulphates (Van Soest et al., 1991). 


\section{Mineral nutrient analysis}

Representative fresh green fodder samples $(150 \mathrm{~g})$ from each treatment were taken in four replicates at harvest, oven-dried at $70^{\circ} \mathrm{C}$ for 48 hours, ground to pass a $0.5 \mathrm{~mm}$ sieve, and stored for chemical analysis. The nitrogen content was determined using Kjeldahl's method. Samples for the determination of mineral nutrients were prepared using dry ashing method (Schouwenberg and Walinge, 1973). Phosphorus was determined using spectrophotometer (Watanabe and Olsen 1965); potassium and sodium by flame photometer (Ryan et al., 2001), Ca, Mg, Mn, $\mathrm{Zn}$ and B by Atomic Absorption Spectrometer (Varian AA 240 FS). Some nutritional elements (N, P, K, Ca, Mg, Zn, Na, and B) for various irrigation waters were also analyzed.

\section{Heavy metals analysis}

Dried and ground plant samples were analyzed for heavy metals $\mathrm{Cd}, \mathrm{Ni}, \mathrm{Pb}$, and $\mathrm{Cr}$ were measured in the dry ash digestion for the fodder dried samples by Graphite Tube Atomizer (GTA 120). Chemical analyses for various irrigation waters were also carried out separately for heavy metals $(\mathrm{Cd}, \mathrm{Ni}, \mathrm{Pb}$ and $\mathrm{Cr}$ ).

\section{Microbial quality analysis}

Barley seedlings produced in this study and irrigated with WW were analyzed for presence of microbial pathogens (total faucal coliforms, E. coli, and nematode eggs).

\section{Experimental design and statistical analysis}

The completely randomized design (CRD) was used with four replicates. Data were statistically analyzed using analysis of variance (ANOVA) according to the statistical package
MSTAT-C (Michigan State Univ., East Lansing, MI, USA). Probabilities of significance among treatments and LSD $(\mathrm{P} \leq$ $0.05)$ were used to compare means among treatments.

\section{Results and Discussion Irrigation water quality}

The analysis of irrigation water used for the various treatments is reported in Table 1 . The salinity of irrigation water was $0.48 \mathrm{dS} / \mathrm{m}$ (tap water) and $1.13 \mathrm{dS} / \mathrm{m}(\mathrm{WW})$. The $\mathrm{pH}$ values were 7.84 for the tap water and 7.82 for the WW. It has been reported that hydroponically grown barley can tolerate salinity of water up to $6 \mathrm{dS} / \mathrm{m}$ without any impact on seed germination or crop yield (Bagci and Yilmaz, 2003).

Nitrogen, $\mathrm{K}, \mathrm{Na}, \mathrm{Cl}$ and $\mathrm{Zn}$ were present in higher concentrations in WW compared to tap water (Table 1). However, similar amounts of $\mathrm{P}, \mathrm{Mg}$, and $\mathrm{B}$ were recorded in both $\mathrm{WW}$ and TW. The concentrations of these elements are considered lower than those recommended for nutrient solutions in crop production (e.g., vegetables) under hydroponic systems according to Benton (2005). Hydroponic green fodder is usually grown with no or little added fertilizers due to the short period of growth (Al-Karaki and Al-Momani, 2010). However, Al-Karaki and Al-Hashimi (2010) recommended that no need to use fertilizer for green barley fodder production under hydroponic conditions, when they found that chemical fertilization at $10 \%$ or $20 \%$ of Hoagland's solution had no significant effects on barley green fodder yield compared to no fertilization (control). 
Table 1. The characteristics of treated wastewater and tap water used for irrigation in this study.

\begin{tabular}{lcc}
\hline Parameter & Tap water & Treated wastewater \\
\hline $\mathrm{EC} \mathrm{dS} / \mathrm{m}$ & 0.48 & 1.13 \\
$\mathrm{pH}$ & 7.84 & 7.82 \\
$\mathrm{DO}(\mathrm{mg} / \mathrm{L})$ & - & 3.1 \\
$\mathrm{BOD}_{5}(\mathrm{mg} / \mathrm{L})$ & - & 10 \\
$\mathrm{COD}(\mathrm{mg} / \mathrm{L})$ & - & 25 \\
$\mathrm{NO}_{3}-\mathrm{N}(\mathrm{mg} / \mathrm{L})$ & 10 & 30 \\
$\mathrm{Cl}(\mathrm{mg} / \mathrm{L})$ & 23 & 134 \\
$\mathrm{PO}_{4}-\mathrm{P}(\mathrm{mg} / \mathrm{L})$ & 5.44 & 5.53 \\
$\mathrm{Ca}(\mathrm{ppm})$ & 67.2 & 42.2 \\
$\mathrm{Mg}(\mathrm{ppm})$ & 16.6 & 16.1 \\
$\mathrm{~K}(\mathrm{ppm})$ & 102 & 114 \\
$\mathrm{Na}(\mathrm{ppm})$ & 81.1 & 500 \\
$\mathrm{Zn}(\mathrm{ppm})$ & 0.013 & 0.025 \\
$\mathrm{~B}(\mathrm{ppm})$ & 0.057 & 0.052 \\
\hline
\end{tabular}

To know the potential risk of heavy metals in irrigation water to plants and hence animals and human beings, it is necessary to evaluate their concentrations in WW. The heavy metal concentrations of WW and TW used in this study are presented in Table 2. Although the nickel, cadmium, chromium, and lead contents in WW are much higher than those in TW irrigation waters, the levels of these elements in WW are lower than the acceptable levels set for irrigation water for crop production according to FAO guidelines (FAO, 1992).

Table 2. Toxic elements content in water used for irrigation and the maximum concentrations of heavy metals in treated wastewater allowed to be used for irrigation according to FAO (1992).

\begin{tabular}{llll}
\hline \multirow{2}{*}{ Metal } & Tap water & $\begin{array}{l}\text { Treated } \\
\text { wastewater }\end{array}$ & $\begin{array}{l}\text { Maximum } \\
\text { concentrations }\end{array}$ \\
\cline { 2 - 3 } Chromium $(\mathrm{Cr})$ & 0.0039 & $\mathrm{ppm}$ & \multicolumn{2}{c}{} \\
\cline { 2 - 4 } Cadmium $(\mathrm{Cd})$ & 0.0005 & 0.0090 & 0.10 \\
Nickel $(\mathrm{Ni})$ & 0.0003 & 0.0032 & 0.01 \\
Lead $(\mathrm{Pb})$ & 0.0041 & 0.0063 & 0.20 \\
& & 0.0147 & 5.00 \\
\hline
\end{tabular}

\section{Microbial quality in produced fodder}

Irrigation with wastewater can represent a major threat to public health (of both humans and livestock), food safety and environmental quality. The microbial quality of wastewater is usually measured by the concentration of the two primary sources of water-borne-fecal coliforms and nematode eggs (Ayers et al., 1992). Presence of E. coli in irrigation waters is used as indicator of fecal pollution as this organism can pose a significant health risks (Dufour, 1997). Results of analysis of produced 
barley fodder seedlings showed no presence of any pathogenic microorganisms (Table 3). However, in a study conducted by Al-Ghazawi et al. (2008) using the same source of WW for production of barley under field conditions, they found no or low populations of some pathogenic organisms in barley seedlings grown in soil under field conditions (Table 3).

Table 3. Analysis of pathogenic microorganism counts in hydroponic and field grown barley irrigated with treated sewage wastewater.

\begin{tabular}{lll}
\hline Parameter & Counts & \\
\hline & $\begin{array}{l}\text { Barley grown } \\
\text { hydroponically } \\
\text { Not found }\end{array}$ & $\begin{array}{l}\text { Barley grown in field } \\
\text { (Al-Ghazawi et al. 2008) }\end{array}$ \\
Total coliforms & Not found & $4.3 \mathrm{MPN} / \mathrm{g}$ \\
E. coli & & $<0.3 \mathrm{MPN} / \mathrm{g}$ \\
Helminthes eggs & Not found & Not found \\
\hline
\end{tabular}

\section{Fodder yield}

Significant differences among various water treatments used in this study were found in green and dry biomass traits (Table 1). Higher yields of fresh green and dry matter were recorded in plants irrigated with WW than for TW (Figure 1 and 2). Table 4 shows barley fodder yields (on fresh green and dry weight basis) and plant heights at harvest. Average green forage yield ranged from 224 tones/ha with tap water to around 320 tones/ha with WW for one production cycle ( 9 days).
A total possible green fodder yield of 5600 and 8000 tons/ha/year can be achieved with the hydroponic system (with 25 harvests per year) using TW and WW in irrigation, respectively. This is more than 66 and 94 times for TW and WW, respectively, greater than the green fodder yield obtained from conventional field grown forage of 85 tons/ha/year. Ghaly et al. (2007) reported that forage wheat grown hydroponically has exceeded some conventional forage crops (e.g. alfalfa) by 98 folds under irrigation with wastewater.

Table 4. Green fodder (fresh and dry) yield, plant height, and ratio of produced green fodder / initial planted seed weight of barley fodder produced under hydroponic conditions and irrigated with treated wastewater and tap water.

\begin{tabular}{lllll}
\hline $\begin{array}{l}\text { Water } \\
\text { Type }\end{array}$ & $\begin{array}{l}\text { Fresh fodder } \\
\text { yield }\end{array}$ & $\begin{array}{l}\text { Dry fodder } \\
\text { yield }\end{array}$ & $\begin{array}{l}\text { Seedling } \\
\text { height }\end{array}$ & $\begin{array}{l}\text { Ratio of produced } \\
\text { fodder / planted } \\
\text { seed weight }\end{array}$ \\
\hline ton/ ha & ton/ ha & $\mathrm{cm}$ & \\
TW & $224 \mathrm{c}^{*}$ & $37.9 \mathrm{c}$ & $18.7 \mathrm{c}$ & $4.74 \mathrm{~b}$ \\
WW mix & $276 \mathrm{~b}$ & $45.2 \mathrm{~b}$ & $20.3 \mathrm{~b}$ & $5.02 \mathrm{~b}$ \\
WW & $320 \mathrm{a}$ & $54.4 \mathrm{a}$ & $22.7 \mathrm{a}$ & $6.00 \mathrm{a}$ \\
\hline $\begin{array}{l}\text { * Means followed by the same letter(s) in each column are not significantly different } \\
\text { at } 5 \% \text { probability level. }\end{array}$ & &
\end{tabular}




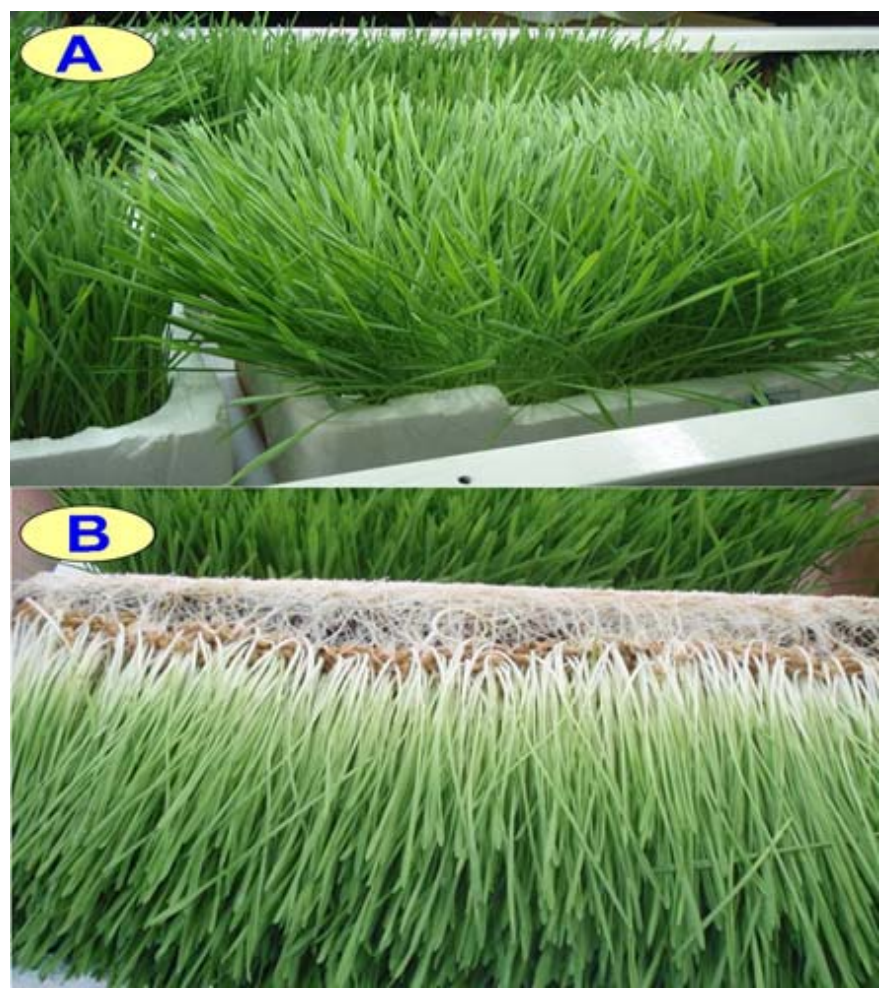

Figure 1. Green fodder ready for harvest (A) and harvested green barley fodder with their root mats $(B)$.

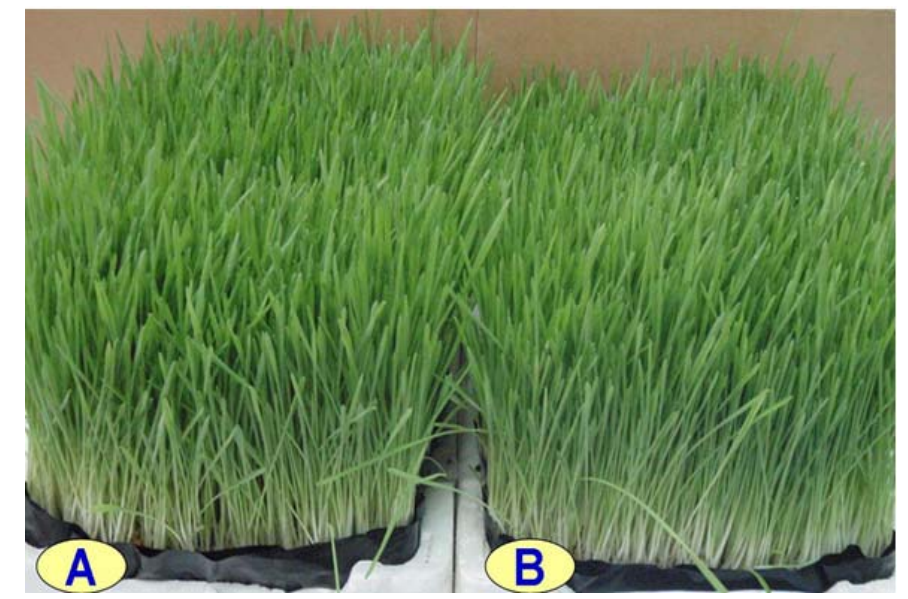

Figure 2. Green fodder biomass produced under irrigation with WW (A) was higher than that irrigated with TW (B).

Results of this study showed that green fodder produced with WW was higher by $40 \%$ than that with TW. Similar trend has been noticed for dry matter production (Table 4). Al-Ajmi et al. (2009) found that total barley fodder yield increased by 1.5 times when irrigated with treated sewage water over yield using tap water. Green forage production has been reported to highly correlate to $\mathrm{N}$ content of irrigation water (Azevedo et al., 2006), 
which conformed to the results of analysis of water used in this study that indicated that WW contains higher $\mathrm{N}$ than tap water.

The heights of barley seedlings obtained in this study were significantly higher when irrigated with WW than irrigation with other types of water. The average barley seedling height ranged between $18.7 \mathrm{~cm}(\mathrm{TW})$ and 22.7 $\mathrm{cm}(\mathrm{WW})$ at harvest. Similar values of plant heights were reported by Al-Hashmi (2008) who obtained barley plants of height $20-22 \mathrm{~cm}$ grown hydroponically and irrigated with tap water. Barley green fodder produced in this study was 4.74 to 6 times more than the initial weight of sown seeds (Table 4). These values are comparable with the ones reported by Sneath and Mclntosh (2003). Al-Hashimi (2008) obtained slightly lower ratios of barley produced fodder to planted seeds weight using tap water in irrigation. However, Al-Karaki (2008) reported that this ratio reached up to 8 times in barley green fodder produced hydroponically.

\section{Water use efficiency}

Hydroponically produced fodder was found to enhance the efficiency of water use (WUE). Brandley and Marulanda (2000) reported that hydroponic green fodder production technique requires only about $10-20 \%$ of the water needed to produce the same amount of crop in soil culture. While Al-Karaki (2010) reported that only $3-5 \%$ of water is needed to produce the same amount of fodder in comparison to that produced under field conditions. In this study, barley plants had utilized 25\% more water when irrigated with TW than with WW, while dry matter production with WW was higher than TW by about $28 \%$ (Table 5 ). This improvement in crop yield might be appreciable and economically feasible. Irrigation with WW was found to use water more efficiently in producing green fodder than irrigation with the other two types of water (TW and WW mix) when used only $1.26 \mathrm{~m}^{3}$ water to produce 1 ton of hydroponic green fodder in comparison to 1.38 and $1.56 \mathrm{~m}^{3}$ water in WW mix and TW, respectively (Table 5). Similar data were revealed by other researchers (Al-Hashmi, 2008; Al-Karaki and Al-Momani, 2010).

Table 5. Total water use and water use efficiency of barley fodder produced under hydroponic conditions and irrigated with different water types.

\begin{tabular}{llll}
\hline Water type & Water use & Water use efficiency & \\
\hline & & & \\
& $\mathrm{m}^{3} /$ ton fresh matter & ton fresh matter $/ \mathrm{m}^{3}$ & ton dry matter $/ \mathrm{m}^{3}$ \\
$\mathrm{TW}$ & $1.56 \mathrm{a}^{*}$ & $0.641 \mathrm{~b}$ & $0.108 \mathrm{~b}$ \\
$\mathrm{WW}$ mix & $1.38 \mathrm{~b}$ & $0.725 \mathrm{a}$ & $0.119 \mathrm{~b}$ \\
$\mathrm{WW}$ & $1.26 \mathrm{~b}$ & $0.794 \mathrm{a}$ & $0.136 \mathrm{a}$ \\
\hline *Means followed by the same letter(s) in each column are not significantly different & \\
at 5\% probability level. &
\end{tabular}

Producing green fodders under hydroponic conditions is a highly efficient process in term of water saving when compared to field production of green fodders as the production of $1 \mathrm{~kg}$ of barley green fodder under field conditions needs 73.5-167 liters of water (Al-
Karaki, 2010). Al-Karaki and Al-Momani (2010) reported that only $14 \mathrm{~kg}$ fresh matter $/ \mathrm{m}^{3}$ water were obtained for field irrigated barley, compared to about $680 \mathrm{~kg}$ fresh matter $/ \mathrm{m}^{3}$ water obtained in this study. This is a tremendous improvement in WUE and 
indicated that hydroponic system could play a significant role in improving water use efficiency in Jordan and other countries in the region with shortage in irrigation water.

\section{Fodder quality}

The proximate analysis for the produced dry fodder showed higher contents of crude protein, neutral (NDF) and acid detergent fiber (ADF) in WW in comparison with barley fodder irrigated with other types of water (Table 6). The protein content in hydroponically produced fodder reached about $27.4 \%$ irrigated with $\mathrm{WW}$, while the values of barley fodder irrigated with WW mix and TW were $24.9 \%$ and $25.2 \%$, respectively (Table 6 ). However, no significant differences were determined between crude fiber and crude fat content in the fodder irrigated with three types of water (Table 6). The values of ADF and NDF in dry fodder ranged between 11-13.4\% for $\mathrm{ADF}$ and between 28.8-32.7\% for NDF (Table 6). Owens (2009) reported that the lower values of $\mathrm{ADF}(<30 \%)$ and $\mathrm{NDF}(<40 \%)$ in the fodder are considered of good nutritional values. The findings related to produce green fodder in this study indicated that irrigation with WW or WW mix may have no adverse effect on health or performance of grazing animals. It offers good use of treated wastewater to increase farmers' benefits. Proximate chemical analyses indicated that barely fodder may probably be superior in some aspects to field grown alfalfa hay used mainly as a source of roughage for livestock in Jordan and the countries of region. Al-Karaki and Al-Momani (2010) reported that hydroponic barley fodder has higher crude protein values and less fiber content than field grown alfalfa forages. Dry matter content in the produced fodder in this study ranged between $16.4 \%$ and $17.1 \%$, and these values are not significantly different between different barley fodders irrigated with different water types (Table 6). The nutrient requirements of the seedlings are quite or partially satisfied from the reserved compounds in the seeds (Bewley, 1997).

Table 6. Proximate analyses of barley irrigated with treated wastewater (WW), tap water (TW) or mixture of WW and TW under hydroponic conditions (dry matter basis).

\begin{tabular}{|c|c|c|c|c|c|c|}
\hline Water type & $\begin{array}{l}\text { Crude } \\
\text { protein }\end{array}$ & Crude fat & $\begin{array}{l}\text { Crude } \\
\text { fiber }\end{array}$ & $\begin{array}{l}\text { Acid } \\
\text { detergent } \\
\text { fiber }\end{array}$ & $\begin{array}{l}\text { Neutral } \\
\text { detergent } \\
\text { fiber }\end{array}$ & $\begin{array}{l}\text { Dry } \\
\text { matter } \\
\text { content }\end{array}$ \\
\hline & & \multicolumn{5}{|l|}{$\%$} \\
\hline Tap water & $25.2 b^{*}$ & $5.2 \mathrm{a}$ & $14.3 \mathrm{a}$ & $11.7 \mathrm{~b}$ & $28.8 \mathrm{~b}$ & $16.4 \mathrm{a}$ \\
\hline WW mix & $24.9 \mathrm{~b}$ & $5.4 \mathrm{a}$ & $15.5 \mathrm{a}$ & $13.4 \mathrm{a}$ & $32.7 \mathrm{a}$ & $16.9 \mathrm{a}$ \\
\hline WW & $27.4 \mathrm{a}$ & $4.8 \mathrm{a}$ & $15.6 \mathrm{a}$ & $13.1 \mathrm{a}$ & $31.2 \mathrm{ab}$ & $17.1 \mathrm{a}$ \\
\hline
\end{tabular}

\section{Nutrient mineral content in barley fodder}

Minerals have a major nutritional significance for livestock and feed deficiencies in elements, such as $\mathrm{Ca}, \mathrm{Fe}, \mathrm{Mn}, \mathrm{Zn}$, can lead to a variety of health problems from anemia to osteoporosis (Liu et al., 2007). Concentration of nutrient elements analyzed in dry barley fodder is presented in Table 7. Except for N, $\mathrm{Mg}$, and $\mathrm{Na}$, there were no significant differences in concentrations of the analyzed elements ( $\mathrm{P}, \mathrm{K}, \mathrm{Ca}, \mathrm{Zn}$, and $\mathrm{Mn}$ ) between those irrigated with WW and with tap water or WW mix. The short growing period of barley fodder under hydroponic conditions and its 
dependency on its own reserved compounds for the early growing stages may be attributed to the low variations of mineral nutrients in the produced fodder irrigated with WW and tap water. The nutrient requirements of the seedlings after germination are quite low and partially satisfied from the reserved compounds in the seeds (Bewley, 1997).

Table 7. The concentration of mineral nutrients in barley green fodder produced under hydroponic conditions and irrigated with different water types (dry matter basis).

\begin{tabular}{|c|c|c|c|c|c|c|c|c|}
\hline $\begin{array}{l}\text { Water } \\
\text { type }\end{array}$ & $\mathbf{N}$ & $\mathbf{P}$ & $\mathbf{K}$ & Mg & $\mathbf{C a}$ & $\mathbf{N a}$ & Zn & Mn \\
\hline & \multicolumn{5}{|c|}{$(\mathrm{mg} / \mathrm{g})$} & & \multicolumn{2}{|c|}{$(\mathrm{mg} / \mathrm{kg})$} \\
\hline TW & $40.3 b^{*}$ & $6.05 \mathrm{a}$ & $8.63 \mathrm{a}$ & $3.78 \mathrm{~b}$ & $3.19 \mathrm{a}$ & $2.50 \mathrm{c}$ & $5.58 \mathrm{a}$ & $9.5 \mathrm{a}$ \\
\hline WW mix & $39.8 \mathrm{~b}$ & $5.65 \mathrm{a}$ & $9.39 \mathrm{a}$ & $4.05 \mathrm{a}$ & $2.94 \mathrm{a}$ & $2.84 \mathrm{~b}$ & $6.14 \mathrm{a}$ & $11.7 \mathrm{a}$ \\
\hline WW & $43.8 \mathrm{a}$ & $5.52 \mathrm{a}$ & $9.26 \mathrm{a}$ & $4.12 \mathrm{a}$ & $2.68 \mathrm{a}$ & $3.10 \mathrm{a}$ & $5.36 \mathrm{a}$ & $12.1 \mathrm{a}$ \\
\hline
\end{tabular}

The high concentrations of $\mathrm{N}$ and $\mathrm{Mg}$ in dry fodder irrigated with WW might be due to their high concentrations in the WW used for irrigation. This might indicate that the $\mathrm{WW}$ is a good source of these minerals that can be used for irrigation under hydroponic conditions. Na levels increased significantly in barley fodder irrigated with WW or WW mix. This is may be a result of their high concentrations in WW used for irrigation. AlAjmi et al. (2009) reported that except for $\mathrm{Ca}$, no significant differences were found between the fodder irrigated with treated wastewater and tap water for the nutrient elements $\mathrm{N}, \mathrm{P}, \mathrm{K}$, $\mathrm{Ca}$, and $\mathrm{Fe}$ contents. Compared to the long term effect of WW irrigation, Rusan et al. (2007) reported that $\mathrm{N}, \mathrm{P}, \mathrm{K}, \mathrm{Cu}, \mathrm{Zn}, \mathrm{Fe}$, and $\mathrm{Mn}$ increased significantly in soils as years of WW irrigation increased in the same lands. Generally, the results of this study indicated that the contents of those essential minerals were available in the produced green fodder around their usual level, thus, WW can be used for irrigation under hydroponic conditions without any adverse effects regarding to these elements.

\section{Heavy metal content in fodder}

Application of WW in irrigation crops usually contain elevated levels of heavy metals (specifically $\mathrm{Cd}$, $\mathrm{Ni}$ and $\mathrm{Pb}$ ) which might accumulate in fodder and cause toxic effects on human by affecting animal products due to direct intake of contaminated fodder (Adriano, 2001). Cadmium concentration in barley fodder was higher in WW than TW or WW mix irrigated plants (Table 8). Cadmium levels found in barley fodder ranged between 0.020 ppm (in tap water) and $0.032 \mathrm{ppm}$ (in WW). These are below the limits set by WHO and FAO which are $0.2 \mathrm{mg} / \mathrm{kg}$ fresh weight for leafy vegetables and fresh herbs (WHO/FAO, 2007).

The low accumulation of $\mathrm{Cd}$ in barley tissues may be attributed to the slightly basic nature of the WW water. Nickel concentrations in barley fodder ranged between $0.057 \mathrm{ppm}$ (tap water) and $0.47 \mathrm{ppm}$ (WW) (Table 8). These are below the limits by FAO for edible crops (FAO, 1992). However, Ni is considered an essential element for small grains (e.g., barley).

Lead $(\mathrm{Pb})$ level in dry fodder was higher in those plants irrigated with $\mathrm{WW}$, ranging between $0.433 \mathrm{ppm}$ (tap water) and $0.903 \mathrm{ppm}$ (WW) on dry matter basis. These levels are lower than those reported by Kabata-Pendias (2000) and Finister et al. (2004) for edible crops. No significant differences were noted for $\mathrm{Cr}$ in dry fodder regardless of water type used in irrigation (Table 8). 
Table 8. The concentration of heavy metals (ppm) in green barley fodder produced under hydroponic conditions and irrigated with different water types.

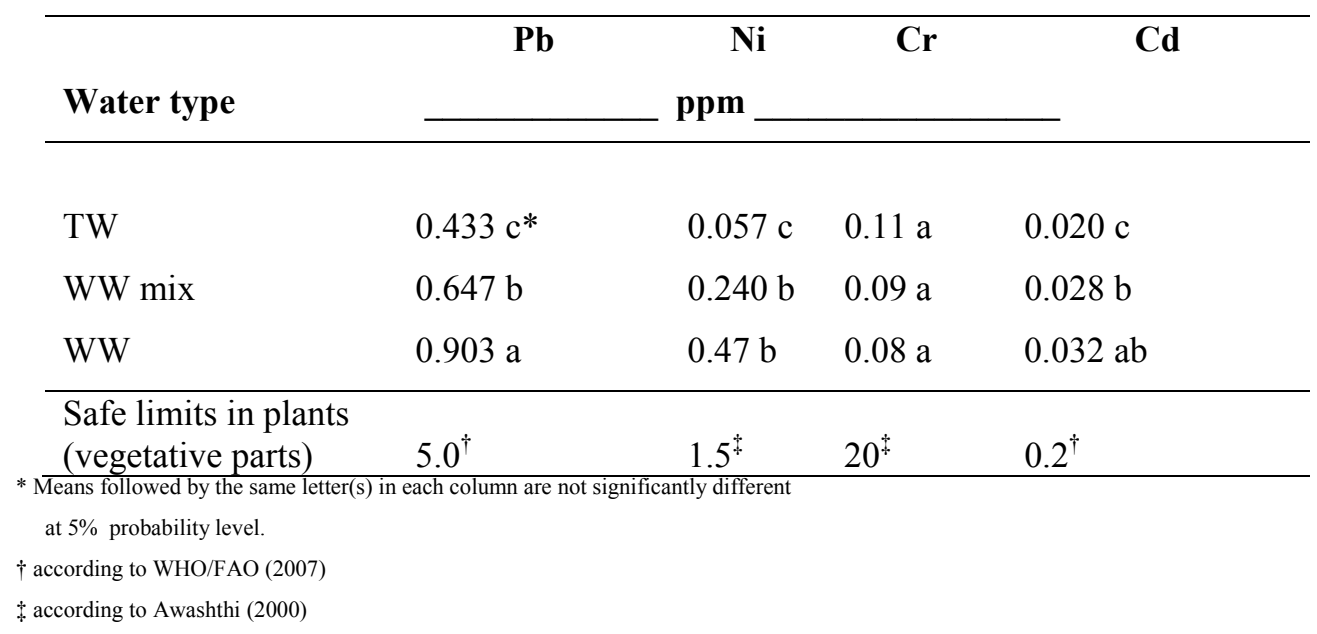

\section{Conclusions}

Hydroponic system is a potential technique for barley fodder production with less water consumption where water is the main limiting factor for agricultural production (e.g., Jordan). Tertiary treated sewage wastewater is a feasible source for irrigation of hydroponically produced barley fodder. The current study shows the superiority of WW irrigated fodder barley over that irrigated with tap water in several aspects related to production and quality of the produced barley crop. This indicated that WW is a good source of nutrients needed for plant growth to promote high yields. The accumulation of heavy metals in the fodder irrigated with WW was apparent, yet below FAO accepted limits. The use of WW in hydroponic systems may reduce the risk of heavy metal accumulation in the soil with prolonged use. It is also considered an environmentally sound waste water disposal practice compared to direct disposal into surface or ground water bodies.

\section{Acknowledgments}

The author is grateful to the Deanship of Scientific Research at Jordan University of Science and Technology (Jordan) for funding this research.

\section{References}

Al Ajmi, A., A. Salih, I. Kadhim, Y. Othman, 2009. Yield and water use efficiency of barley fodder produced under hydroponic system in GCC countries using tertiary treated sewage effluents. J. Phytol. 1(5):342-348.

Adriano, D. C. 2001. Trace Elements in Terrestrial Environments: Biogeochemistry, Bioavailability and Risks of Metals. Springer-Verlag, New York.

Al-Ghazawi. 2007. Wastewater reuse in agriculture: global trends and local issues. Proceedings of the conference "Scientific Research on Treated Wastewater Reuse and Biotechnology in Jordan" 17 November 2007. Jordan Society for Scientific Research, Amman, Jordan. pp 322.

Al-Ghazawi, Z., J. Amayreh, L. Rousan and A. Hijazi. 2008. Wastewater reuse for agriculture pilot project at Jordan University of Science and Technology. In: I. Al Baz, R. Otterpohl and C. Wendland (Eds.). pp 284-297. Efficient Management of Wastewater: its treatment and reuse in water scarce countries. Springer-verlag, Berlin, Germany.

Al-Hashmi, M. M. 2008. Hydroponic green fodder production in the Arabian Gulf Region. MSc. Thesis, Faculty of Graduate Studies, Arabian Gulf University, Bahrain. 
Al-Karaki, G. N. 2008. Application of hydroponic culture in production of green fodder. Training workshop, Arabian Gulf University. Bahrain 21-23 April, 2008.

Al-Karaki, G. N. 2010. Hydroponic green fodder: alternative method for saving water in dry areas. Proceedings of the "Second Agricultural Meeting on Sustainable Improvement of Agricultural and Animal Production and Saving Water Use. September 2010, Sultanate of Oman.

Al-Karaki, G. N. and M. Al-Hashmi. 2010. Effect of mineral fertilization and seeding rate on barley green fodder production and quality under hydroponic conditions. Proceedings of the "International Conference \& Exhibition on Soilless Culture", 8-13 March 2010, Singapore.

Al-Karaki, G. N. and N. Al-Momani. 2010. Evaluation of some barley cultivars for green fodder production and water use efficiency under hydroponic conditions. Jordan J. Agri Sci (In press).

Ansar, M., Z. I. Ahmed, M. A. Malik, M. Nadeem, A. Majeed and and B. A. Rischkowsky. 2010. Forage yield and quality potential of winter cereal-vetch mixtures under rainfed conditions. Emir. J. Food Agric. 22(1):25-36.

AOAC. 2000. Official Methods of Analysis. 17th Ed. Association of Official Analytical Chemists, Gaithersburg, MD.

Awasthi, S. K. 2000. Prevention of food Adulteration Act No. 37 of 1954. Central and State Rules as Amended for 1999, third ed. Ashoka Law House, New Delhi.

Ayres, R. M., R. Stott, D. D. Mara and D. L. Lee. 1992. Wastewater reuse in agriculture and the risk of intestinal nematode infection. Parasitol. Today 8:32-35.

Azevedo, M. R. Q. A, A. König, N. E. Beltrão, B. S. O. de Ceballos, C. A. V. de Azevedo, and T. L. Tavares. 2006. Effects of the irrigation with treated wastewater on fodder corn production. Paper number
062094. 2006 ASAE Annual Meeting, Portland, Oregon, USA.

Bagci, S. A., H. E. A. Yilmaz. 2003. Determination of the salt tolerance of some barley genotypes and the characteristics affecting tolerance. Turk. J. Agric. For. 27:253-260.

Benton, J. 2005. Hydroponics; A practical Guide for the Soilless Grower. $2^{\text {nd }} \mathrm{Ed}$. CRC press, USA.

Bewley, J. D. 1997. Seed germination and dormancy. The Plant Cell. 9:1055-1066.

Boue, S., T. Wiese, S. Nehls, M. Burow, S. Elliott, C. Carterwientjes, B. Shih, J. McLachlan and T. Cleveland. 2003. Evaluation of the estrogenic effects of legume extracts containing phytoestrogens. J. Agric. Food Chem. 51(8):2193-9.

Bradley, P. and C. Marulanda. 2000. Simplified Hydroponics to Reduce Global Hunger. Acta Hort. 554:289-295.

Chung, T. Y., Nwokolo, E. N. and J. S. Sim. 1989. Compositional and digestibility changes in sprouted barley and canola seeds. Plant Foods Human Nutr. 39:267278.

Cuddeford, D. 1989. Hydroponic Grass. In Practice. 11(5):211-214.

Dufour, A. P. 1977. Escherichia coli: The Fecal Coliform. In: A.W. Hoadley and B. J. Dutka (Eds.). pp. 48-58. Bacterial Indicators / Health Hazards Associated with Water. American Society for Testing and Materials.

Finister, M. E., K. A. Gray and H. J. Binns. 2004. Lead levels of edibles grown in contaminated residential soils; a field survey. Sci. Total Environ. 320:245-257.

FAO (Food and Agriculture Organization of the United Nations). 1992. Wastewater quality guidelines for agricultural use. In: Pescod, M.B. (Ed) Wastewater treatment, and use in agriculture - FAO irrigation and drainage paper 47. Rome, Italy. pp 25-35. 
Ghaly, A. E., H. A. Farag and M. Verma. 2007. A hydroponic system for purification of anaerobically treated manure and production of wheat as nutritional forage crop. Am. J. Agric. Biol. Sci. 2:206-217.

Harb, M. and F. Al-Awawdeh. 2008. Forage: situation, challenges and solutions. Jordanian Agric. Eng. Magazine 85:18-23.

Hook, J. E. 1981. Movement of phosphorus and nitrogen in soil following application of municipal wastewater. In: D. W. Nelson, D. E. Elrick and K. K. Tanji (Eds.). pp. 241-255. Chemical mobility and reactivity in soil systems. Soil Science Society of America, Madison.

Kabata-Pendias, H. 2000. Trace Elements in Soils and Plants, Third ed., CRC Press, Boca Raton, FL.

Kanauchi O, T. Nakamura, K. Agata, K. Mitsuyama and T. Iwanaga. 1998. Effects of germinated barley foodstuff on dextrin sulfate sodium-induced colitis in rats. J. Gastroenterol. 33(2):179-88.

Leontovich, V. P. and M. A. Bobro. 2005. Technology of continuous growing of hydroponic fodder. Russian Agric. Sci. $33: 239-241$.

Liu, K., K. L. Peterson and V. Raboy. 2007. Comparison of the phosphorus and mineral concentrations in bran and abraded kernel fractions of a normal barley (Hordeum vulgare) cultivar versus four low phytic acid isolines. J. Agric. Food Chem. 55:4453-4460.

Malkawi, S. 2007. Reclaimed Water Policy, Standards and Uses in Jordan. Ministry of Water and Irrigation, Water Authority of Jordan, Water Reuse and Environment Unit.Amman-Jordan. http://www.umich. edu/ ipolicy/Policy\%20Papers/water.pdf.

Malkawi, H. I. and M. J. Mohammad. 2003. Survival and accumulation of microorganisms in soils irrigated with secondary treated wastewater. J. Basic Microbiol. 43:47-55.
MOA (Ministry of Agriculture). 2008. The state report of the agricultural sector in Jordan. Amman, Jordan.

Mooney, J. 2005. Growing cattle feed hydroponically. Meat and livestock Australia. p.30.

Nsheiwat, Z. B. 2007. Wastewater use in Jordan: an introduction. Wastewater Reuse -Risk Assessment, Decision-Making and Environmental Security. pp. 73-79.

Owens, E. 2009. Fodder solutions Equine Digestibility Trial. Fodder Solutions. Solutions Equine Digestibility Trial. Equine University.

Rababah, A. and A. Al-Shuha. 2009. Hydroponics reducing effluents heavy metals discharge. Water Sci. Tech. 59:175183.

Rababah, A. A. and N. J. Ashbolt. 2000. Innovative production treatment hydroponic farm for primary municipal sewage utilization. Water Res. 34(3):825834.

Ryan, J., G. Estefan, and A. Rashid. 2001. Soil and Plant Analysis Laboratory Manual. 2 ${ }^{\text {ed }}$. International Center for Agricultural Research in the Dry Areas ICARDA, Aleppo, Syria.

Robertson, J. B. and P. J. Van Soest. 1981. The detergent system of analysis. In: W. P. T. James and O. Theander (Eds.). pp. 123158. The Analysis of Dietary Fiber in Food. Marcel Dekker, NY.

Rusan, M. J. M., S. Hinnawi and L. Rousan. 2007. Long term effect of wastewater irrigation of forage crops on soil and plant quality parameters. Desalination 215:143152.

Schouwenberg, V., J. C. Walinge. 1973. Methods of analysis for plant material. Agric. Univ. Wageningen, The Netherlands.

Sezen, S. M, G. Celikel, A. Yazar, S. Tekin and B. Kapur. 2010. Effect of irrigation management on yield and quality of tomatoes grown in different soilless media 
in a glasshouse. Sci. Res. Essays 5(1):4148.

Sidle, R. C., J. E. Hook and L. T. Kardos. 1977. Accumulation of Heavy Metals in Soils from Extended Wastewater Irrigation. J. Water Poll. Control Fed. 49:311-318.

Sneath, R. and F. McIntosh, 2003. Review of hydroponic fodder production for beef cattle Department of Primary Industries, Queensland, Australia.

Snow, A. M. and A. E. Ghaly. 2008. Use of Barley for the Purification of Aquaculture Wastewater in a Hydroponics System. Amer. J. Environ. Sci. 4(2):89-102.

Tudor, G., T. Darcy, P. Smith, and F. Shallcross. 2003. The intake and live weight change of drought master steers fed hydroponically grown, young sprouted barley fodder (Autograss), Department of Agriculture Western Australia.

Van Soest, P. J., J. B. Robertson, B. A. Lewis. 1991. Methods for dietary fiber, neutral detergent fiber and non-starch polysaccharides in relation to animal nutrition. J. Dairy Sci. 74:3583-3597.
Vaillant N, F. Monnet, H. Sallanon, A. Coudret, and A. Hitmi. 2004. Use of commercial plant species in a hydroponic system to treat domestic wastewaters. J. Environ. Qual. 33(2):695-702.

Watanabe, F. S. and S. Olsen. 1965. Test of an ascorbic acid method for determining phosphorus in water and $\mathrm{NaHCO} 3$ extract for soil. Soil Sci 21:677-678.

WHO/FAO. 2007. Joint FAO/WHO Food Standard Programme Codex Alimentarius Commission 13th Session. Report of the Thirty Eight Session of the Codex Committee on Food Hygiene. Houston, United States of America.

Xua J., L. Wub, A. C. Chang and Y. Zhang. 2010. Impact of long-term reclaimed wastewater irrigation on agricultural soils: A preliminary assessment. J. Haz. Mater. 183:780-786.

Yang, Z. S. Zheng, J. Chena and M. Suna. 2008. Purification of nitrate-rich agricultural runoff by a hydroponic system. Biores. Techn. 99:8049-8053. 